\section{Outcry as 'scientific' badger cull is launched to target TB}

[LONDON] Conservation and animal welfare groups have launched a campaign to stop a $\mathfrak{£} 17.5$ million (US\$30 million) governmentsponsored scientific experiment that will cull at least 12,500 badgers over five years.

The experiment, announced last week, is designed to investigate the belief, widely held among farmers, that badgers with tuberculosis (TB) pass the disease on to cattle. It will be phased in over the next two years.

The National Federation of Badger Groups (NFBG) says the experiment is "morally unacceptable and practically unworkable". The Edinburgh-based group Advocates for Animals takes a similar view.

Elaine King, conservation officer at the NFBG, claims the experiment could lead to the "total eradication of badgers" in the areas where culling is to take place.

"The government has clearly underestimated the strength of public feeling on this issue," warns King. "While the federation does not condone activities that are unlawful, it is inevitable that members of the public will demonstrate and take direct action.”

However, the National Farmers' Union called the experiment "an important step", which will provide hope to farming families "that bovine tuberculosis is on the way to being solved".

Bovine tuberculosis is a relatively small problem in British dairy farming, but it is growing steadily. More than 500 cattle died from tuberculosis last year, compared with 125 in 1991. Infected badgers are widely thought to spread the disease through their use of cattle pastures. However, the suspected link has not been confirmed, and there is no diagnostic test available to detect tuberculosis in living badgers.

The culling experiment is among a package of measures proposed to the government by an expert group of scientists chaired by John Krebs, chief executive of the Natural Environment Research Council.

The government has also agreed to invest in developing a vaccine to protect cattle from tuberculosis, though this will take between 10 and 15 years

Meanwhile, the experiment will take place in 30 trial sites, each occupying 100 square kilometres in different parts of England where the incidence of cattle tuberculosis has historically been high. Badgers will be lured into traps and then shot. The experiment was designed and will be analysed by a separate group of scientists chaired by John Bourne, professor of animal health at the University of Bristol.

Ten sites will have as many badgers removed as possible. In another 10, only

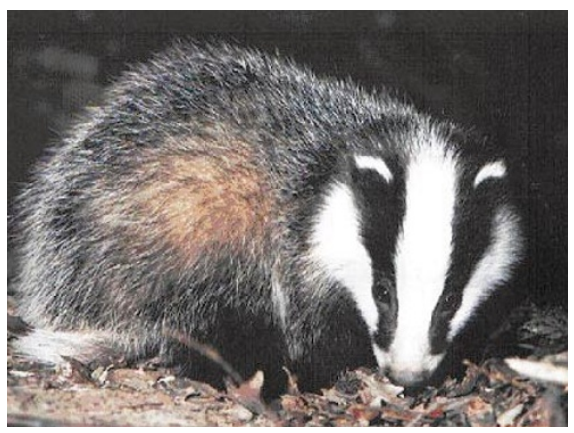

Losing streak: more than 12,000 badgers will be killed to find out if they spread tuberculosis.

badgers from social groups associated with tuberculosis will be removed. No badgers will be removed from the final 10 sites. On each site, researchers will monitor levels of cattle tuberculosis to see whether, and how much, these are affected by the cull. Laboratory studies will quantify the numbers of dead badgers with tuberculosis.

Jeff Rooker, the government's food safety minister, says the decision to kill badgers was a difficult but necessary one. Bovine TB, he said, needed to be better understood, given the implications for humans who eat meat and drink milk.

But Rooker added that the government had incorporated animal welfare concerns into the experiment. As a results of talks with badger groups, he said, the badgers would be caught in traps instead of snares, which are more efficient but considered to be crueller.

There would also be a closed season between February and April each year to reduce the risk of trapping nursing mothers, ensuring that dependent cubs are not left to starve underground. In addition, farmers would be banned from killing badgers outside the trial areas, which cover less than 0.1 per cent of the area of Great Britain.

But according to the NFBG, these measures do not go far enough. One particular concern, according to King, is the risk of the experiment breaking down through continued — though now illegal — badger culling by farmers. She says many wildlife trusts are likely to refuse culling on their land.

Stephen Harris, professor of environmental sciences at the University of Bristol, who works on badger and bovine tuberculosis, is another critic. He questions the data's end use. Large-scale badger culling would not be a long-term solution even if the experiment confirmed a link between badger tuberculosis and the bovine disease, he claims. And, says Harris, the possibility of tuberculosis passing from cows to badgers also needs to be investigated. EhsanMasood ndia's short cow drags Roslin Institute into controversy

[NEW DELHI] The world's smallest cattle breed, nearly extinct in its Indian home, is at the centre of a controversy involving Scotland's Roslin Institute. DNA from the Vechur cow was allegedly smuggled out of India to the Edinburgh institute - where Dolly the sheep was cloned - to be used in patentable research on transgenic animals.

The claims were made by Vandana Shiva, a prominent conservationist and president of the Research Foundation for Science, Technology and Ecology. They were denied by the Roslin Institute. "We have no programme to preserve germplasm from UK or foreign breeds. We don't understand what this is about," says assistant director Harry Griffin.

"I am yet to find out the truth in these allegations," says Moti Lal Madan, director general of the Indian Council of Agricultural Research (ICAR). "Two weeks ago we asked the Roslin Institute for comments and we are awaiting their reply."

The Vechur, no bigger than a large goat, needs little food, thanks to its size - typically $90 \mathrm{~cm}$ tall and $1 \mathrm{~m}$ long - but its milk is very rich in fat. Tolerant of heat and resistant to most diseases including foot-and-mouth, it has been the focus of ICAR-funded genetic research in Kerala Agricultural University (KAU) at Thrissur since 1989, when only eight could be found for study. Today there are about 100 on the university farm.

University authorities say that Roslin scientists asked to do research on the cattle in 1994, but that these requests were denied. Shiva alleges that germplasm was later smuggled to the UK by KAU scientists. She also claims that Roslin's web site, a year ago, contained 36 references to its work on the Vechur cow and that these were erased after reports of smuggling appeared in the Indian media.

Dr Sosamma Iype, head of animal genetics and breeding at KAU, says the charges are baseless. She also denies that she spent time at Roslin during 1996, "though our students have been sent there for training," she says. At a press conference this month, KAU vicechancellor Shyamasundaram Nair denied any wrongdoing by KAU scientists and said that if Roslin had the Vechur germplasm it might have come from other sources.

India's 28 breeds of cattle and 200 millionstrong herd are a gold-mine of germplasm, according to Sher Ali, an animal geneticist at the National Institute of Immunology in New Delhi. "We never bother to study their valuable genes until somebody steals them to exploit commercially," he says.

Madan says, however, "If anyone wants a disease-resistant gene it can be found in many other breeds in India." K.S. Jayaraman 